\title{
Bütün Yönleri ile Anne Sütü Bankacılığı*
}

\author{
Breast Milk Banking in All Aspects
}

\section{Aylin Bayındır Gümüşi, Hülya Yardımcıi}

\author{
i Arş. Gör., Ankara Üniversitesi, Sağlık Bilimleri Fakültesi, Beslenme ve Diyetetik Bölümü, https://orcid.org/0000-0002-1311-2429
}

iiDoç. Dr, Ankara Üniversitesi, Sağlık Bilimleri Fakültesi, Beslenme ve Diyetetik Bölümü, https://orcid.org/0000-0002-2664-4176

Öz

Anne sütü, evrensel olarak yaşamın ilk altı ayında yenidoğan beslenmesinin temelini oluşturmaktadır. Bu dönemde sadece anne sütü ile beslenme ve iki yaşına kadar ek besinler ile birlikte anne sütü ile beslemeye devam etme, sağlık otoriteleri tarafından önerilmektedir. Anne sütü, bebeğin uygun bir biçimde büyüme ve gelişmesinin sağlanmasında elzem olup yenidoğan beslenmesinde inek sütü, bebek mamaları ve uygunsuz başlanan ek besinlerden belirgin şekilde üstündür. Ancak annenin, bebeğin anne sütüne ihtiyacı olduğu zaman ölümü, bebeğin emmeyi reddetmesi ve annenin sütten kesilmesi, yanlış emzirme tekniklerinin kullanılması veya annenin bebeğini emzirmeyi reddetmesi gibi durumlarda, yenidoğanın anne sütüne erişimi olanaksız hale gelmektedir. Bu durum, yenidoğanın henüz olgunluğunu tamamlamamış olan immün sistem, ürogenital sistem, gastrointestinal sistem ve nöromüsküler sistem başta olmak üzere tüm sistemleri için en uygun olan besinden yoksun kalmasına yol açmakta ve tüm bunların sonucunda sağlık problemlerine neden olabilmektedir. Çok eski yıllardan bu yana çözüm olarak, anne sütüne erişemeyen bebeklerini sütanneler emzirmiştir. Bunun yanı sıra sütannelere ulaşım sorunu ve enfeksiyon riskleri açısından alternatif olarak anne sütü bankaları oluşturulmaya başlanmıştır. Günümüzde birçok ülkede kurulmuş ve kurulması planlanan anne sütü bankaları bulunmaktadır. Ancak bu anne sütü bankalarının kullanımında, çeşitli noktalara dikkat etmek gerekmektedir. Bunlar; anne sütünün uygun prosedürlerin takibi ile belirli şartları sağlayan annelerden toplanması, pastörizasyon gibi çeşitli yöntemler ile sağlık açısından güvenliğinin sağlanması, uygun koşullarda depolanıp gereksinimi olan bebeğe teslim edilmesidir. Anne sütü bankalarının bütün yönleri ile ele alındığında, toplum açısından ekonomik, dini, inançlar ve kültürel yönlerden çatışma oluşturmaması önem taşımaktadır. Bu derlemenin amacı, dünya genelinde yaygınlığı artan anne sütü bankacılığına genel bir bakış açısı kazandırmaktır.

Anahtar Kelimeler: Donör Süt, Anne Sütü, Anne Sütü Bankacılı̆̆ı, Pastörizasyon, Prematüre, Yenidoğan

\section{ABSTRACT}

Breast milk is universally the basis of newborn nutrition in the first six months of life. Exclusively breastfeeding in this period, and continuation of breast milk until the age of two are recommended by health authorities. Breast milk is essential for the optimal growth and development of the newborn and is significantly superior to cow's milk, infant formulas, and inappropriate complementary foods in newborn nutrition. However, in cases such as death when the baby needs breast milk, the refusal of the baby to breastfeed and the mother's weaning, the use of wrong breastfeeding techniques, or the mother's refusal to breastfeed her baby, the newborn cannot access breast milk. This situation causes the newborn to be deprived of the nutrients most suitable for the all systems especially immune system, urogenital system, gastrointestinal system, and neuromuscular system, which has not yet matured and consequently causes health problems. Since ancient times, as a solution, milk-mothers have breastfed their babies who cannot reach breast milk. However, human milk banks have started to be established as an alternative to these milk-mothers in terms of transportation problems and infection risks. Today, there are human milk banks established and planned to be established in many countries. However, in the use of these human milk banks, it is necessary to pay attention to various issues. These issues; collecting breast milk from mothers who meet certain conditions by following appropriate procedures, ensuring its safety in terms of health with various methods such as pasteurization, storing it under appropriate conditions, and delivering it to the baby in need. When human milk banks are considered from all aspects, it is important that they do not create conflicts in terms of economy, religion, beliefs, and cultural aspects of society. The purpose of this review is to provide an overview of breast milk banking, which has become widespread worldwide.

Keywords: Donor milk, Breast milk, Human milk banking, Pasteurization, Premature, Newborn

*Lokman Hekim Dergisi, 2021; 11 (2): 212-222

DOI: $10.31020 /$ mutftd.830954

e-ISSN: 1309-8004, ISSN 1309-761X

Geliş Tarihi - Received: 24 Kasım 2020; Kabul Tarihi - Accepted: 2 Mart 2021

Iletişim - Correspondence Author: Aylin Bayındır Gümüş <dytaylin@outlook.com> 


\section{Giriş}

Anne sütünün, yaşamın ilk altı ayı için en uygun besin olduğu ve özellikle yaşamın ilk iki yılında sağlıklı bebek beslenmesinin önemli bir parçası olması gerektiği evrensel olarak kabul edilmektedir. ${ }^{1}$ Dünya Sağlık Örgütü (DSÖ) emzirmenin önemini, bebeğin genel sağlığı ve büyüme-gelişmesi için temel taşlardan biri şeklinde ifade etmektedir. Illk altı ay sadece anne sütü ile beslenmeyi (exclusive breastfeeding), altı ay-iki yaş arasında emzirmenin devam ettirilmesini desteklemektedir. ${ }^{2}$ Diğer sağlık otoritelerinin önerilerine bakıldığında, Avrupa Pediatrik Gastroenteroloji, Hepatoloji ve Beslenme Derneği (European Society for Paediatric Gastroenterology Hepatology and Nutrition-ESPGHAN) en az dört ay ${ }^{3}$ ve Avrupa Allerji ve Klinik İmmünoloji Akademisi (European Academy of Allergy and Clinical Immunology-EAACI) besin alerjilerinin önlenmesi için, yaşamın ilk 4-6 ayı sadece anne sütü ile beslenmeyi önermektedir. ${ }^{4}$

Anne sütü ile beslenmenin hem anne hem de bebek açısından oldukça önemli yararları bulunmaktadır. Bebeğin büyüme ve gelişmesini destekleyici ve anne-bebek çiftinin genel sağlığını geliştirici olması bu yararlar arasındadır. Dolayısı ile yenidoğanın beslenmesi için alternatif tüm besinlerden belirgin şekilde üstündür. İnek sütü bazlı ve bitki bazlı bebek mamaları, anne sütünün yağ, protein ve karbonhidrat bileşimine benzetilmeye çalışılsa da anne sütünde bulunan birçok biyoaktif faktörün karmaşıklığını veya işlevselliğini tam olarak içermemektedirler. ${ }^{5,6}$ Bu durum tek bir beslenme önleminin (anne sütü) bir bütün olarak topluma nasıl geniş sağlık faydaları sağlayabileceğinin bir örneğidir. ${ }^{7}$ Tüm bu nedenlere dayalı olarak anne sütü alamayan veya yetersiz alan bebekler için anne sütü bankası kavramı ortaya çıkmıştır. Anne sütü bankaları, bebeğin anne sütüne ulaşamadığı veya yetersiz olduğu durumlarda bağışlanan, süt depoları olarak işlev görmektedir. Günümüzde anne sütü bankalarının etkinliği ve yaygınlığı giderek artmaktadır. ${ }^{8}$

\section{Tarihçe}

On dokuzuncu yüzyılda bebekleri için sütü olmayan annelerin bebeklerine süt sağlamak amacı ile uygulanan "sütannelik" kavramı sıklıkla kullanılmakta idi. ${ }^{9}$ Daha eski yıllara bakıldığında, sütannelik kavramı Babiller zamanına kadar uzanmakta ve Hammurabi Kanunu’na göre sütannelerin emzirme karşılığında arpa, yün gibi çeşitli hediyeler aldıkları bildirilmektedir. ${ }^{10}$ Bu kavramın milattan önceye dayandığı ve XX. yy'a kadar yaygın olarak devam ettiği belirtilmektedir. ${ }^{11}$

Sütannelerin her zaman mevcut olmaması veya süt yolu ile bulaşabilecek enfeksiyon riskleri açısından sütannelik kavramına alternatif olarak anne sütü bankaları ilk defa 1909 yılında Avusturya'nın Viyana kentinde ortaya çıkmıştır. Viyana'dan kısa bir süre sonra, Amerika Birleşik Devletleri'nde Boston Floating Hastanesi'nde de açılmış ve dünyanın dört bir yanına yayılmıştır. 1960'lı yıllarda yüksek kaliteli bebek mamalarının geliştirilmesi gibi yenidoğan tıbbi bakım ve bebek beslenmesindeki gelişmeler ile anne sütü bankacılığına karışı yönelim azalmıştır. HIV virüsü ve AIDS vakalarının 1980'li yıllarda ortaya çıkışı ile birçok anne sütü bankası kapansa $\mathrm{da}^{8}$, anne sütünün eşsiz olması nedeni ile günümüzde anne sütü bankacılığına ilgi tekrar artmıştır. Anne sütü bankacılığı faaliyeti ekonomik, dini ve kültürel faktörler nedeni ile dünya ülkeleri arasında farklılıklar göstermektedir. Hindistan, Vietnam, Çin ve Japonya gibi bazı Asya ülkelerinde birçok anne sütü bankası açılmıştır. Dünyada sınırları giderek genişleyen anne sütü bankacılığı faaliyetleri anne sütüne erişemeyen yenidoğan beslenmesinde gün geçtikçe önemli bir alternatif kaynak haline gelmektedir. Anne sütü bankalarından en çok fayda sağlayan grup özellikle prematüre bebeklerdir. ${ }^{12}$ Prematüre bebeklerin anne sütü ile beslenmesini teşvik etmek için Emzirme Tıp Akademisi, Avrupa Pediatrik Gastroenteroloji Hepatoloji ve Beslenme Derneği (ESPGHAN), Amerikan Pediatri Akademisi (APA) ve DSÖ gibi pediatri sağlık otoritelerinin önerileri, anne sütü bankacılığına duyulan bu ilginin artışı ile sonuçlanmaktadır. ${ }^{8,9}$ Dolayısı ile sağlık otoriteleri, anne sütünün bulunmadığı durumlarda erken doğmuş bebekler için pastörize insan donör sütünü önermektedir. Bu aşamada şu an pek çok ülkede faaliyet 
göstermekte olan anne sütü bankaları, çeşitli nedenlerle anne sütü alamayan bebekler için önemli beslenme alternatiflerinden birini oluşturmaktadır. ${ }^{13}$ Günümüzde donör sütün faydalı bileşenleri mamalara kıyasla daha fazla olduğu için kullanımı önerilmektedir. ${ }^{8}$

\section{Farklı Ülke ve Kültürlerde Uygulama Örnekleri ve Bakış Açısı}

Anne sütünün yararlarına dair çalışmaların günden güne artması ve dünyada iletişim ağlarının çoğalması ile anne sütünü paylaşmak yaygın hale gelmiştir. Anne sütü bankaları, en kurumsallaşmış süt paylaşım yöntemidir ve doğru uygulamalar ile en güvenli olanıdır. Ancak farklı ülkelerde farklı şekillerde uygulanmaktadır. ${ }^{14}$ Avrupa Süt Bankası Birliği (European Milk Bank Association - EMBA) verilerine göre Avrupa ülkelerinde kurulan ve kurulması planlanan anne sütü bankalarına Tablo 1' de yer verilmiştir. ${ }^{15}$

Tablo 1. Avrupa ülkelerinde kurulan ve kurulması planlanan anne sütü bankaları

\begin{tabular}{|c|c|c|}
\hline Ülkeler & Kurulu Anne Sütü Bankası & Kurulması Planlanan Anne Sütü Bankası \\
\hline Avusturya & 2 & - \\
\hline Belçika & 4 & - \\
\hline Bulgaristan & 1 & - \\
\hline Hırvatistan & 1 & - \\
\hline Çek Cumhuriyeti & 4 & - \\
\hline Danimarka & 2 & - \\
\hline İspanya & 15 & 2 \\
\hline Estonya & 1 & - \\
\hline Finlandiya & 17 & - \\
\hline Fransa & 36 & - \\
\hline Almanya & 28 & 9 \\
\hline Yunanistan & 2 & - \\
\hline Macaristan & 8 & - \\
\hline İtalya & 37 & - \\
\hline Litvanya & 2 & 1 \\
\hline Hollanda & 1 & - \\
\hline Norveç & 12 & - \\
\hline Polonya & 11 & 3 \\
\hline Portekiz & 1 & 1 \\
\hline Romanya & - & 1 \\
\hline Rusya & 3 & - \\
\hline Sırbistan & 3 & - \\
\hline Slovakya & 6 & - \\
\hline Slovenya & - & 1 \\
\hline İsveç & 28 & - \\
\hline İsviçre & 7 & - \\
\hline Türkiye & - & 2 \\
\hline Birleşik Krallık & 16 & - \\
\hline Toplam & 248 & 20 \\
\hline
\end{tabular}

Ülkeler bazında bakıldığında Brezilya, anne sütü bankacılı̆ında dünya lideri konumundadır. Ülke 1930'lara dayanan bir uygulama geçmişine sahiptir ve saygın araştırma kuruluşu Oswaldo Cruz Vakfı'ndaki (FIOCRUZ) bilim insanlarının tavsiyelerine dayanarak, bir bankayı işletmek için gerekli tüm adımları belirleyen on yıllık bir halk sağlığı yasası da bulunmaktadır. Brezilya, Amazon eyaletlerinden São Paulo'ya kadar ülkenin 26 eyaletinde en az bir banka ile 217 süt bankasına ve 126 süt toplama noktasına sahiptir. ${ }^{16}$ Ülke genelinde Brezilya İnsan Sütü Bankaları Ağı'na kayıtlı 224 anne sütü bankası ve 215 toplama merkezi bulunmakta ve kadınlar donör olma konusunda teşvik edilmektedir. ${ }^{17}$ Brezilya'da hükümetin desteklediği anne sütü bankacılığını da kapsayan ulusal emzirme kampanyaları ile 1980'den 2009'a kadar bebek ölümlerinde \%50 oranında azalma ve sağlık harcamalarından yaklaşık 540 milyon dolarlık tasarruf sağlanmıştır. Anne sütü bankacılığı aynı zamanda Avrupa ülkelerinde de yaygınlaşma eğilimindedir. Özellikle İtalya'da, süt bankaları yüzyılın başından bu yana çok daha yaygın hale gelmiştir. İtalya Bağış̧ı İnsan Süt Bankaları Birliği tarafından yayımlanan veriye göre, italyan süt bankaları 2007 ve 2012 yılları arasında toplam bağış hacminde artış 
eğilimi kaydetmiştir. Norveç'te ise süt bankaları pastörize edilmemiş süt kullanmaktadır. Bu durum anne sütü donörlerinin sıkı bir kontrol ve taramasını gerektirmektedir. Yüksek emzirme oranı, süt bankalarında mevcut olan süt miktarını etkilemekte ve annenin kendi sütü mevcut değilse veya tedarik yetersiz ise tüm erken doğmuş bebeklere donör süt sunulabilmektedir. ${ }^{18}$ Bağışlanan sütün pastörize edilip edilmemesi konusu sıklıkla tartışılmaktadır. Şimdiye kadar Norveç'teki görüş pastörizasyona karşı çıkmıştır. Norveç’teki sağlık sistemi, süt bağışını kan bağışına benzer şekilde ele almakta ve böylece süt donörden tüketiciye maksimum güvenlik koşulları sağlanarak ulaştııılmaktadır. Bağışçıarın testleri de düzenli olarak tekrarlanmakta ve bu konuda çok katı hareket edilmektedir. Öte yandan HIV ve hepatit görülme oranlarının çok düşük olması, donör sütün pastörize edilmemesini düşündürmüştür. Bu düşüncenin temel amacı, patojen mikroorganizmaları azaltmak için gerekli olan pastörizasyona katılan yüksek sıcaklıkların, bebeklere sağlık açısından fayda sağlayan ve çiğ sütte aktif bulunan proteinlerin bir kısmını denatüre etmesidir. ${ }^{14}$

Farklı kültür ve inanışlar, anne sütü bankacılığı konusunda farklı bakış açılarına sahip olabilmektedirler. Dünyadaki dinlerin çoğunun süt bağışı ile ilgili büyük bir sorunu bulunmamaktadır. Hristiyanlık, Budizm veya Hinduizm'de, anne sütü paylaşımı ile ilgili herhangi bir dini sorun bulunmamakta ve hatta teşvik edilmektedir. İnsandan insana kan transfüzyonunu yasaklayan Yehova topluluklarında da, anne sütünün paylaşılması konusunda katı kurallar bulunmamaktadır. ${ }^{19}$ Müslümanlıkta süt paylaşımı bir ahlaki davranış olarak kabul edilmektedir. Emzirme, kuvvetle teşvik edilmekte ve Kuran-ı Kerim'de emzirme ile ilgili birçok ayet bulunmaktadır (Örneğin "Ve tüm anneler için, iki yaşına gelene kadar çocuğunuzu emzirmelisiniz.") ${ }^{20}$ Müslümanlıkta bir annenin çocuklarını emzirmesi çok erdemli bir davranış olarak düşünülmekte ancak anne sütünün satılmasını veya uygunsuz bir biçimde kullanılmasını desteklememektedir. Anne sütünün bağışının bir erdem olarak desteklenmesine rağmen donör bir anne tarafından beş defadan fazla emzirilen iki yaşından küçük herhangi bir çocuğun, donör annenin çocukları ile kardeş kabul edilmektedir. Kardeş oldukları gerekçesi ile bu bebeklerin ileride birbirleri ile evlenemeyecekleri anlamına gelmektedir. Bu durum süt paylaşımının öznel vakalarında bir sorun yaratmasa da hastane düzeyinde bir süt paylaşım programının kurulmasını karmaşık hale getirmektedir. ${ }^{19}$ İrlanda'da 1997 yılında batılı ülkelerde yaşayan Müslümanların sorunlarına çözüm olabilmek amacı ile artan farkındalık üzerine Avrupa Fetva ve Araştırma Konseyi kurulmuştur. Konsey, 2004 yılında preterm bebeğe kendi annesinin sütü olmadığında donör süt kullanımına yönelik toplanmış ve yoğun bakım ünitesindeki preterm bebeğe verilen donör sütün akrabalık oluşturmadığı kararını almıştır. Anne sütü bankaları konusuna sıcak bakan konsey, süt bağışında bulunmayı ve bankalar aracılığı ile süt almayı uygun bulmaktadır. ${ }^{21}$ Ancak Türkiye'de henüz anne sütü bankaları bulunmamaktadır.

\section{Anne Sütü Bankacılığı Süreci}

Anne sütü biyolojik bir ürün olup ister bebeğin kendi annesinden ister donör bir anneden olsun, kontaminasyon konusunda her zaman endişe duyulmaktadır. Olası kontaminantlar, bakteri ve virüsler de dahil olmak üzere bulaşıcı ajanlar ve çevredeki toksik bileşenler gibi diğer maddelerdir. Donör anne sütünün pastörizasyonunda kullanılan işlemler, kirleticilerin giderilmesinde oldukça etkilidir. Anne sütü bankaları, gelen sütün bakteriyel tarama yaklaşımlarında farklılık gösterebilmekte ancak pastörizasyon sonrası bakteriyolojik kültür taramaları rutin olarak gerçekleştirilmektedir. ${ }^{22}$

Pastörizasyon işlemi görmeden resmi olmayan yollar kullanılarak yapılan doğrudan süt paylaşımı, bebekleri bakteriyel kontaminasyon ve sitomegalovirüs, hepatit virüsleri ve HIV dahil olmak üzere viral bulaşma gibi bir dizi olası riske maruz bırakmaktadır. Doğrudan süt paylaşımı genellikle tek bir donör anneden süt kullanılarak düzenlendiğinden, ilaçlar veya diğer kontaminantlar, havuzlanmış süt ürünlerinden daha yüksek bir risk olabilmektedir. ${ }^{23}$ Birçok ülkede anne sütü bankalarının işleyişini düzenleyen bir birimin olmaması süt bankacılığında güvenilirliğin korunması için endişe yaratmaktadır. Bu nedenle anne sütü bankaları öngörülemeyen riskleri elimine etmek için uygun önlemlerin alınmasını sağlayacak şekilde yönetilmeli ve 
düzenlenmelidir. ${ }^{24}$ Hükümetlerin süt bankacılığını düzenleyen özel yasalara sahip olduğu Brezilya gibi ülkelerde güvenlik ile ilgili zorlukların önemli ölçüde azaldığı görülmektedir. ${ }^{25}$

\section{Donör Olma Şartları ve Donör Sütten Yararlanan Bebekler}

Donör popülasyonu, kendi bebeklerinin beslenme gereksinimlerinden ödün vermeden gönüllü olarak diğer bebekler için anne sütü vermek isteyen sağlıklı anneler tarafından oluşmaktadır. Sağlam bebek kliniklerine giden, bebekleri yenidoğan yoğun bakım ünitelerinde olan veya bebeklerini kaybeden ancak sütlerini bağışlamaya istekli olan anneler de donör olabilmektedir. Bağış̧ılara genellikle herhangi bir ödeme yapılmamakta, gönüllülük ilkesine dayandırılmaktadır. Toplumda anne sütü bağışı için başta kitle iletişim araçları olmak üzere çeşitli yollar ile farkındalık yaratmak, bağış̧ıların motive edilmesine yardımcı olabilmektedir. ${ }^{26}$ Çoğu donör anne sütü, bir süredir kendi bebeğini emziren ve salgılanan süt miktarının kendi bebeğinin gereksinimini karşılarken, süt bağışlamalarına izin verecek kadar çok olduğunu fark eden kadınlar tarafından bağışlanmaktadır. Süt bağış̧̧ısı olarak kabul edilebilmek için kadınlar yasal olmayan maddeler veya ilaç kullanmamalıdır. Hem anne hem de bebek için süt bağışının uygunluğu hekimler tarafından onaylamalıdır. Bu aşamada süt bankası, donörlerin sağlık geçmişini taramakta ve test için kan örneği almaktadır. Bağış yapan anne genellikle HIV-1, HIV-2, insan T hücresi lösemi virüsü 1 ve 2, hepatit B, hepatit $C$ ve sifiliz açısından taranmaktadır. ${ }^{8}$ Donör olma kriterleri konusunda henüz ortak kabul gören bir rehber bulunmadığı için, ülkeler kendi şartlarını belirleyebilmektedir. Ulusal olarak kabul edilen ve tanınan yönergelere sahip ülkeler arasında Avusturya, Danimarka, Almanya, Norveç, Slovakya, İspanya, İsveç ve İsviçre bulunmaktadır. İsveç ve İspanya'dan yakın zamanda güncellenen (2017-2018) ulusal yönergelerin İngilizce çevirileri EMBA web sitesindeki bağlantılar aracılığı ile indirilebilmektedir. ${ }^{15}$ Almanya, Avusturya ve İsviçre'de anne sütü bankalarının geliştirilmesi amacı hazırlanan rehberde, donör annenin kendi bebeğine yeterli anne sütü sağladıktan sonra fazla sütünü anne sütü bankasına bağışlaması ve mikrobiyolojik testlerin sonuçlarına göre sütün kabulü esas alınmaktadır. ${ }^{27}$

Kuzey Amerika Insan Sütü Bankacıllğı Birliği'nin (The Human Milk Banking Association of North AmericaHMBANA) verilerine göre tüm gereklilikler yerine getirilirse, donöre sütünü depolayabileceği uygun bir kap sağlanmakta ve uygun süt ekspresyon yollarına ilişkin talimatlar verilmektedir. Donör, sütü mekanik pompa veya manuel sağım ile almakta ve süt bankasına teslim etmeden önce ev buzdolabının dondurucu bölmesinde saklamaktadır. Süt daha sonra, anne tarafından ya da süt bankası tarafından sağlanan bir nakil hizmeti ile süt bankasına taşınmaktadır. Soğuk zincirin kesinlikle bozulmaması önemlidir, bu nedenle evden süt bankasına nakil sırasında özel soğutma torbaları veya soğutma kutuları kullanılmalıdır. ${ }^{8}$

Söz konusu süt bağışı bebekler açısından ele alındığında, prematüre bebeklerin hem donör sütü alan en büyük grup, hem de anne sütü almanın en büyük faydasını elde eden grup olduğu ifade edilmektedir. Anne sütü, bebeğin henüz olgunlaşmamış bağırsakları üzerinde beslenme ile ilişkili etkiler uygulamakta ve böylece tam enteral beslenmeye daha erken ulaşımasını sağlamaktadır. Anne sütü prematüre bebekleri özellikle nekrotizan enterokolit (NEK) ve sepsis olmak üzere yüksek mortalite oranına sahip olan iki hastalıktan korumaktadır. ${ }^{28}$ Amerika Birleşik Devletleri'nde anne sütü ile ilgili 2016 yılında yayınlanan bir rehberde, donör ve alıcı kriterleri aşağıdaki gibi tanımlanmıştır. ${ }^{29}$

Donör olma koşulları; (i) herhangi bir sağlık sorununun olmadığına dair sözlü beyan, (ii) serolojik test sonuçlarının (HIV-1 ve HIV-2, HTLV-I ve HTLV-II, Hepatit B, Hepatit C, Sifilis) negatif olması, (iii) taranan donörlerin her gebelikte yeni donör olarak kabul edilmesi, (iv) son 12 ay içerisinde kan transfüzyonu yapılmaması, (v) son 12 ay içerisinde organ veya doku nakli olmaması, (vi) düzenli olarak günde iki kadehten fazla alkol kullanmaması veya son 24 saat içerisinde bu miktara eşdeğer alkol almamış olması, (vii) reçetesiz veya düzenli olarak reçeteli ilaç kullanımının olmaması, (viii) megadoz vitamin veya farmakolojik bitkisel 
preparatların kullanılmaması, (ix) vitamin desteği almayan vegan birey olmaması, (x) yasal olmayan madde veya tütün ürünlerinin kullanılmaması, (xi) silikon göğüs implantına sahip olmaması, (xii) hepatit, sistemik hastalıklar veya HIV, HTLV, TB gibi kronik enfeksiyon öyküsünün olmamasıdır.

Donör sütten yararlanabilen bebekler; (i) enfeksiyon veya NEK açısından riskli bebekler, (ii) gastrointestinal anomali veya kısa bağırsak sendromu gibi diğer intestinal cerrahisi olanlar, (iii) 1500 gramın altında doğanlar, (iv) amino asit bozuklukları gibi metabolik hastalığa sahip olanlar, (v) annenin bebeğini tamamen besleyemeyeceği bebekler, (iv) doğumdan sonraki ilk günlerde kendi annesinin sütü olmayan bebeklerdir.

\section{Bağış Süreci}

Anne sütü bankalarının işleyiş ve süreçleri, ülkelerin özellikleri ve olanaklarına göre değişkenlik göstermektedir. Ancak genellikle genellikle bağışlanan sütün toplanması ve işlenmesi için standart yöntemleri takip etmektedirler. Birleşmiş Milletler Çocuklara Yardım Fonu (UNICEF), bu sürecin nasıl olması gerektiğini adım adım bildirmektedir. Bu adımlar şu şekildedir; (i) Alanında uzmanlaşmış bir hemşire, konu ile ilgilenen laktasyon dönemindeki anneyi, anne sütünü bağışlama süreci ve amacı hakkında danışmanlık yapar, bilgilendirir ve tarar. (ii) Ekipteki personelin yardımı ile anne sütü bağış̧ılardan manuel yöntemler veya göğüs pompaları kullanılarak toplanır. (iii) Toplanan çiğ anne sütü bir dondurucuda saklanır. Her bir kabın üzerine bağış̧ının adı, toplama tarihi ve saati ve toplanan anne sütü miktarı gibi bilgiler eksiksiz ve ayrıntılı bir biçimde etiketlenir. (iv) Anne sütünü pastörize etmek için bir gece öncesinde buzdolabında çözdürülür. Birden fazla vericiden gelen anne sütü daha sonra, süt yeni kaplara aktarılırken kontaminasyonu önlemek için filtrelenmiş havanın dolaşımını kontrol eden bir havalandırma cihazı olan laminer akışı bir başlık altında toplanır. (v) Her parti $62.5^{\circ} \mathrm{C}^{\prime}$ de 30 dakika pastörize edilir. Pastörizasyon bakterileri, virüsleri ve diğer mikroorganizmaları azaltır ve anne sütünün raf ömrünü uzatır. Her partiden alınan numuneler, güvenlik ve kaliteyi sağlamak için mikrobiyolojik testler için pastörizasyondan önce ve sonra hastane laboratuvarına gönderilir. Pastörize süt daha sonra bir dondurucuda $-20^{\circ} \mathrm{C}$ 'de saklanır. (vi) Süt bankasından anne sütü almak için alıcıların, doktor tarafından reçete edildiğini gösteren bir belgeye sahip olması ve gerekli formları doldurması gerekmektedir. (vii) Dondurulmuş pastörize anne sütü, taşıma sırasında sıcaklığını korumak için buz veya jel dondurma paketleri olan bir soğutucuya konur. Çözüldükten sonra süt 24 saat içinde tüketilmelidir. Bu aşamaların dışında ayrıca donörler süt bankası tarafından önerilen meme temizliği ve göğüs pompalama prosedürleri hakkında bilgilendirilmeli ve süt depolamasında uygun kaplar kullanılmalıdır. ${ }^{30,31}$ Anne sütüne uygulanan işlemler Şekil 1'de özetlenmiştir. ${ }^{8}$

Anne sütü bankalarında uygulanan işlemler kadar bu işlemleri uygulayan ve denetleyen ekibi oluşturan meslek grupları da önemlidir. Kuzey Amerika Anne Sütü Bankacılığı Birliği'nde, her bağımsız süt bankasında medikal direktör (uzman bilirkişi), doktor, diyetisyen, emzirme danışmanı, hemşire ve enfeksiyon uzmanından oluşan bir yönetim kurulunun bulunması gerektiği bildirilmektedir. Bu kurulun, süt bankacılığı süreçlerini ve politikalarını gözden geçirmek için düzenli olarak toplanması ve süt bankalarının günlük işleyişinin laktasyon danışmanları yönetiminde olması önerilmektedir. ${ }^{32}$ 


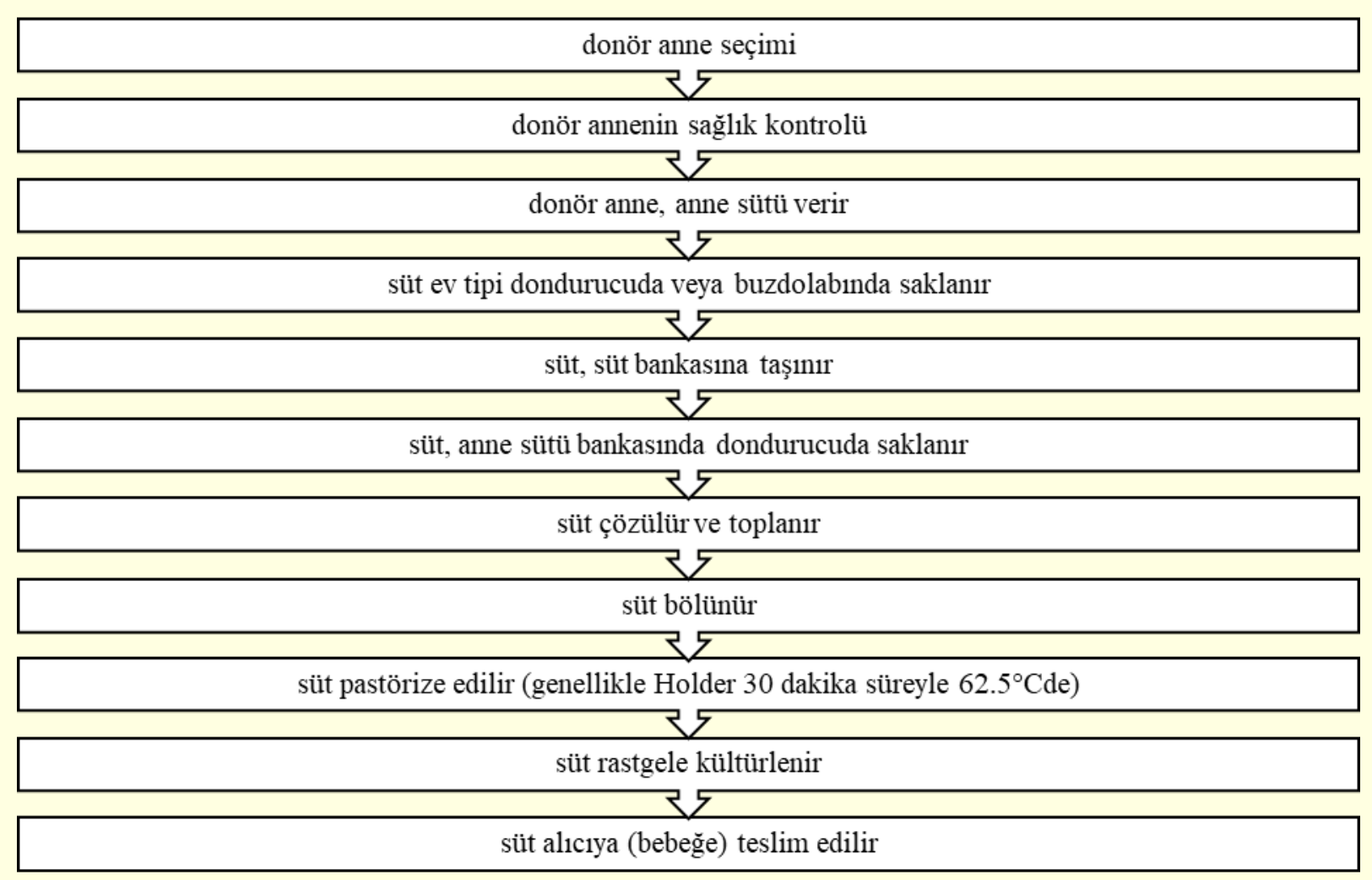

Şekil 1. Anne Sütüne Uygulanan İşlemler

\section{Sütün Güvenliğini Sağlama ve Uygulanan Yöntemler}

Düşük Sıcaklıkta Uzun Süre Pastörizasyon (Holder Pastörizasyon): Anne sütünün protein ve enerjisi (toplam yağ ve laktoz) düşük sıcaklıkta uzun süre pastörizasyon (Holder) işleminden sonra korunmakta veya bir miktar azalma gözlenebilmektedir. Oligosakkaritler, A ve E vitaminleri, laktoz, uzun zincirli çoklu doymamış yağ asitleri ve epidermal büyüme faktörü de Holder pastörizasyon sonrasında korunmaktadır. ${ }^{33}$ Son zamanlarda yapılan bir çalışmada, Holder pastörizasyon işleminden sonra D vitamini konsantrasyonunda \%10-20 oranında bir azalma olduğu bildirilmiştir. ${ }^{34}$ Holder pastörizasyon işlemi sonrası, demir, bakır ve çinko konsantrasyonları da bir miktar azalmaktadır. ${ }^{33}$ Çoklu doymamış uzun zincirli yağ asitleri de dahil olmak üzere anne sütünün yağ asitleri Holder pastörizasyonu işleminden etkilenmemekte, ancak bu işlem lipaz enzimini tamamen etkisiz hale getirmektedir. ${ }^{35}$ Safra tuzu bağımlı lipaz enzimi, ince bağırsaktan yağların emilimi için gereklidir. Yenidoğan, küçük miktarlarda lipaz enzimini sentezleyebildiğinden anne sütünde bulunan lipaz bu eksikliği desteklemektedir. Safra tuzu bağımlı lipaz enzimi, nispeten düşük sıcaklıklarda $\left(45-55^{\circ} \mathrm{C}\right)$ etkisiz hale gelmektedir ve Holder pastörizasyon işlemi sonrasında enzimin aktivitesi tamamen kaybolmaktadır. ${ }^{34}$ Holder pastörizasyonun anne sütünün toplam protein içeriği üzerinde etkisi yoktur, ancak yüksek sıcaklıkta kısa süre pastörizasyon işleminden sonra mevcut lizin içeriğinde \%29 gibi önemli bir oranda azalma olmaktadır. ${ }^{36}$ Anne sütünde bulunan antioksidanlar; NEK, prematüre retinopatisi, bronkopulmoner displazi ve diğer prematürite komplikasyonları ile ilişkili serbest radikallerin etkisine karşı doğal savunma sisteminin bir parçasıdır. Holder pastörizasyon işlemi sonrasında anne sütünün toplam antioksidan kapasitesinde azalma olmaktadır. ${ }^{37}$

Yüksek Sıcaklıkta Kısa Süreli Pastörizasyon (UHT): Yüksek sıcaklıkta kısa süreli pastörizasyon yöntemi, anne sütünün özelliklerini korumada daha etkili olmaktadır. Ancak bu yöntem anne sütü bankalarında kullanılmamaktadır. Bu yöntemin anne sütünün toplam protein, folat, $B_{12}$ vitamini ve $C$ vitamini üzerinde olumlu ya da olumsuz herhangi bir etkisi olmadığı bildirilmiştir. ${ }^{38}$ Pastörize edilmemiş anne sütü ile karşılaştırıldığında, yüksek sıcaklıkta kısa süreli pastörizasyonun Holder pastörizasyonda olduğu gibi anne 
sütündeki alkalen fosfataz ve lipaz miktarını önemli ölçüde azalttığı saptanmıştır. ${ }^{33}$ Ayrıca yüksek sıcaklıkta kısa süreli pastörizasyon sonucunda mevcut lizin içeriğinde önemli ancak düşük seviyede (\%14) bir azalma ile yansıtılan protein kalitesi üzerinde bir etki bildirilmiştir. ${ }^{36}$ Sonuç olarak, deneysel veriler yüksek sıcaklıkta kısa süreli pastörizasyonun Holder pastörizasyonda olduğu gibi çoğu mikroorganizmayı yok etmek için etkili olduğunu, anne sütünün biyolojik kalitesini koruma konusunda Holder pastörizasyona kıyasla daha iyi olduğunu göstermektedir. ${ }^{33}$

Ultrason ve Isı Kombinasyonu (Termoultrasonik İşlem): Sütün ısıl pastörizasyona kıyasla biyoaktif bileşenlerinin daha fazlasını korunmasını sağlayan yeni bir tekniktir. Ancak mevcut deney sistemi küçük hacimler ile sınırlıdır ve ölçeklendirilmesi gerekmektedir. Ultraviyole ışınlar; bakteri, virüs ve maya gibi mikroorganizmaları yok etmektedir. Termoultrasonik işlem için veriler çoğunlukla deneyseldir ve anne sütü bankacılığında rutin kullanımın fizibilitesi henüz kanıtlanmamış olmakla birlikte ${ }^{33}$ geliştirilerek ileride kullanılması olasıdır.

Yüksek Basınçlı işleme (HPP): Yüksek basınçlı işleme tekniği, katı ve sıVı besinlerdeki patojenik mikroorganizmaları inaktive etmek için kullanılmaktadır. Bu işlemde kısa bir süre için yüksek hidrostatik yüksek basınç (genellikle 400-800 $\mathrm{MPa}$ ) uygulanmaktadır. Basınçlandırma ile kimyasal bileşim, renk ve aromadaki değişiklikler, ısıl işlemden kaynaklanan değişikliklerden daha azdır. ${ }^{33}$ HPP sütün fizikokimyasal özelliklerini (özellikle protein kalitesini) önemli düzeyde etkilemektedir. Umut verici bir teknoloji gibi görünmekte, ancak rutin olarak kullanılmadan önce daha fazla araştırma yapılması gerekmektedir. ${ }^{8}$

Ohmik Isıtma: Ohmik ısıtma, besin maddesinden elektrik akımı geçirilerek homojen ve hızlı ısıtma sağlayan bir yöntem olup ${ }^{39}$ anne sütünün ısıl işlemi için araştırılan yeni bir teknolojidir. Geleneksel termal işleme sırasında yavaş iletim ve geleneksel ısı transferi nedeni ile önemli ürün kalitesi hasarı oluşabilmektedir. Bu yöntemde ise besinin dengeli ısınması sayesinde ürün daha kaliteli olmaktadır. Bu teknik ile yapılan ilk deneysel çalışmalar, sütün protein örüntüsünde $72^{\circ} \mathrm{C}^{\prime}$ lik bir sıcaklıkta hiçbir değişiklik olmadığını ve $78^{\circ} \mathrm{C}^{\prime}$ lik bir sıcaklıkta sadece küçük değişiklikler olduğunu göstermiştir. Ancak sıcaklık $85^{\circ} \mathrm{C}$ olduğunda önemli derecede değişiklikler olduğu saptanmıştır. ${ }^{32}$

\section{Sütün Dağıtımı ve Maliyet Etkililiği}

Yenidoğan yoğun bakım ünitesinde emzirmeyi teşvik etmenin ve donör anne sütünü kullanmanın finansal etkisinin tam olarak ölçülmesi zordur. Donör anne sütünün işleme maliyeti, NEK ve NEK'e bağlı gelişmiş kısa bağırsak sendromu vakasının yönetilmesi maliyetine kıyasla oldukça azdır. Bu nedenle donör anne sütü kullanımı, gastrointestinal komplikasyonlarda küçük bir azalma olsa bile süt bankacılığının işletme maliyetlerini geri kazandırabilmektedir. Donör anne sütü kullanımı; hastanede kalış, sepsis ve NEK süresini azaltarak maliyet etkinliğini desteklemektedir. Tamamlayıcı bir fayda olarak, donör süt bankalarının toplumda genel olarak emzirme bilincini arttırabileceği ve böylece bir bütün olarak nüfusa daha geniş faydalar sağlayabileceği düşünülmektedir. ${ }^{30}$

\section{Türkiye'de Anne Sütü Bankacılığına Bakış}

Türkiye'de kurulması planlanan ve Sağlık Bakanlığı'nın gündeminde olan anne sütü bankaları henüz oluşturulmamıştır. Sağıı Bakanlığı'nın yaptığı açıklama ile projenin alt yapısı sağlamlaştırılıp yeniden düzenlenmesi planlanmaktadır. Anne sütü bankası ile aynı işlevi görecek "sütanne merkezleri" kurularak "sütannelik ve sütkardeşliği" projesinin etkin hale getirilmesi de planlanan projeler arasındadır. ${ }^{21}$ Türkiye'de anne sütü bankacılığına ilişkin ilk adım, 2011 yıında başlamıştır. ${ }^{40}$

"Türk Anne Sütü Merkezi” adı altında bir anne sütü bankası modeli geliştirilmiştir ancak henüz bu model hayata geçirilmemiştir. Bu modelin içeriği aşağıdaki gibidir: ${ }^{41}$ 
- Süt bağışı yapacak annenin seçimi ve sütün sağılması, güvenli bir şekilde saklanması, taşınması ve işlenmesinde uluslararası bilimsel standartların esas alınması

- "Süt kardeşliği/akrabalığı" kavramının dikkate alınması

○ Bir bebek için sadece bir bağışçı anneden alınan sütün kullanılması

○ Bağışı yapan annenin bebeği ile bağış sütünü alacak bebeğin aynı cinsiyetten olması

- Ailelerin birbiri ile tanışması, bağışçı anne ve bağış sütünü alan bebeğin kimlik bilgilerini içeren süt cüzdanın olması ve elektronik kayıt sisteminin oluşturulması

- Yenidoğan yoğun bakım ünitelerinin bulunduğu merkezlerde anne sütü bankaları kurulması, bu kurumların Sağlık Bakanlığı tarafından denetlenmesi

- Süt bağışı için kesinlikle gönüllülük prensibinin esas alınarak, bağış̧̧ı anneye para ödenmemesi ve süt satılmaması

- Bağış̧ı annenin öncelikle kendi bebeğini emzirdikten sonra fazla olan sütünü bağışlaması

- Prematüre ve hasta yenidoğan bebeklere öncelikle kendi annelerinin sütünün verilmesine dikkat edilmesi; sütün olmadığı ya da yetmediği durumlarda mama vermek yerine anne sütü bankasından süt sağlanması

Ayrıca anne sütü bankalarının kurulması ve devamlıı̆ı̆ının sağlanması için, altyapı çalışmalarının sağlam temellere dayandırıması ve donör sorununun yaşanmaması için özellikle doğurganlık çağındaki kadınların bu konuda yeterli bilgi ve bilinç düzeyine sahip olması gerekmektedir. Türkiye'de 2009 yılında Erzurum ilinde yapılan bir çalışmada, çalışmaya katılan kadınların çoğunun anne sütü bankacılığı hakkında bilgi sahibi olmadığı görülmüştür. Katılımcılara anne sütü bankacılığı hakkında bilgi verildikten sonra kadınların çoğu Türkiye'de bu bankaların oluşturulmasını istediklerini $(\% 64,3)$ ve gerekirse sütlerini $(\% 64,0)$ bağışlayabileceklerini ifade etmişlerdir. Ancak annelerin \%48,6'sı bebeklerini emziremedikleri durumlarda da bankadan süt almak istememiştir. Çalışmanın sonucunda, dini ve kültürel inançların anne sütü bankacılığı konusu üzerine etkisinin incelenmesi gerektiği belirtilmiştir. ${ }^{42}$ Bunun yanı sıra 2014 yılında annelerin anne sütü bankacılığı ile ilgili bilgi ve görüşlerini değerlendirmek amacı ile İzmir ilinde yapılan bir başka çalışmada, katılımcı annelerin \%41,6'sı anne sütü bankası adını duymuş olup, \%58,4'ü ise hiç duymamıştır. Annelere, bebeğini emzirmeye engel bir durum yaşadığı takdirde ne yapardınız şeklinde sorulduğunda, \%47,52'si anne sütü bankasından yararlanmayı düşünmüş ve $\% 8,2$ 'si daha önce sütannelik yapmıştır. Annelerin süt bankacılığı uygulamasını duyması ve desteklemesinin, bu konu açısından olumlu bir yaklaşım olduğu ifade edilmiştir. ${ }^{43}$

\section{Sonuç ve Öneriler}

Beslenme sürecinde bebeklerin gereksinimlerinin yetişkinlerin gereksinimleri ile aynı değildir. Yenidoğanın doğduğu andan itibaren en güvenilir, ekonomik ve uygun olan besin kendi annesinin sütüdür. Kendi annesinin sütünü çeşitli nedenlerden dolayı alamayan özellikle prematüre bebeklere süt kaynağı olması amacı ile bazı ülkelerde anne sütü bankaları kurulmuştur. Anne sütü bankaları sayesinde süt bağışı daha güvenilir ve ulaşılabilir hale gelmiştir.

Donör sütün faydalı bileşenlerinin mamaya kıyasla daha fazla olduğu bilinmekte ve günümüzde kullanımı Birleşmiş Milletler Çocuklara Yardım Fonu (UNICEF), Dünya Sağlık Örgütü (DSÖ) gibi uluslararası sağlık otoriteleri tarafından desteklenmektedir. Türkiye'de ise henüz anne sütü bankası bulunmamakla birlikte Sağlık Bakanlığı'nın sürdürdüğü çalışmalar mevcut olup aynı işlemlerin uygulanarak sütanne merkezlerinin kurulması projeler arasında yer almaktadır. 


\section{Bilgi}

Destekleyici herhangi bir kurum/kuruluş yoktur. Çalışma daha önce herhangi bir kongrede sunulmamıştır. Yazı ile ilgili herhangi bir mali ya da diğer çıkar çatışması yoktur.

\section{Araştırmacı Katkı Oranı Beyanı}

Aylin Bayındır Gümüş: Fikir/kavram, tasarım, kaynak taraması, makalenin yazımı. Hülya Yardımcı: Fikir/kavram, tasarım, denetleme/danışmanlık, analiz veya yorum, kaynak taraması, makalenin yazımı, eleştirel inceleme.

\section{Kaynaklar}

1. Boland M. Exclusive breastfeeding should continue to six months. Paediatr Child Health 2005;10(3):148.

2. who.int [Internet]. Guideline: Counselling of Women to Improve Breastfeeding Practices. Geneva: World Health Organization; 2018 [cited 2021 Jan 10]. Available from: https://www.who.int/nutrition/publications/guidelines/counselling-womenimprove-bf-practices/en/

3. Fewtrell $\mathrm{M}$, et al. Complementary feeding: a position paper by the European Society for Paediatric Gastroenterology, Hepatology, and Nutrition (ESPGHAN) Committee on Nutrition. J Pediatr Gastroenterol Nutr 2017;64(1):119-32.

4. Muraro A, et al. EAACl food allergy and anaphylaxis guidelines. Primary prevention of food allergy. Allergy 2014;69(5):590-601.

5. Bilgen $\mathrm{H}$, Kültürsay $\mathrm{N}$, Türkyılmaz $\mathrm{C}$. Türk Neonatoloji Derneği sağılılı term bebeğin beslenmesi rehberi. Türk Pediatri Arşivi 2018;53(1):128-37.

6. Newcomb PA, et al. Lactation and a reduced risk of premenopausal breast cancer. N Engl J Med 1994;330(2):81-7.

7. who.int [Internet]. Breastfeeding in the 21. century [cited 2020 Aug 28]. Available from: https://www.who.int/pmnch/media/news/2016/breastfeeding_brief.pdf

8. Haiden N, Ziegler EE. Human milk banking. Ann Nutr Metab 2016;69(2):7-15.

9. Çalbayram NÇ. Anne sütü bankaları. Türk Dünyası Uygulama ve Araştırma Merkezi Yenidoğan Dergisi 2017;2(2):517-28.

10. Öz E. Çiviyazılı belgelere göre Mezopotamya'da sütannelik hizmeti, sütanne olarak qadištum kadınları ve kutsal kitaplarda sütannelik uygulaması. Electronic Turkish Studies 2015;10(13):235-48.

11. mdsoar.org [Internet]. Infant Feeding Practices as Personal and Cultural Constructions [cited 2020 Oct 4]. Available from: https://mdsoar.org/bitstream/handle/11603/2796/RMu_6.20_Final\%20Capstone.pdf?sequence=1\&isAllowed=y

12. Kabasakal E, Bozkurt Ö. Türkiye'de anne sütü merkezi girişimlerinin değerlendirilmesi ve sistem önerisi. JCM 2019;9(4): 417-23.

13. Martin CR, Ling PR, Blackburn GL. Review of infant feeding: key features of breast milk and infant formula. Nutrients 2016;8(5):279.

14. milkgenomics.org [Internet]. Very Small Babies Benefit from Either Human or Cow-based Milk Fortifiers [cited 2020 Oct 2]. Available from: https://milkgenomics.org/wp-content/uploads/2018/08/August-2018-SPLASH.pdf

15. europeanmilkbanking.com [Internet]. Active and Planned Milk Banks [cited 2020 Sep 28]. Available from: https://europeanmilkbanking.com/

16. redeblh.fiocruz.br [Internet]. The Brazilian Network of Human Milk Banks [cited 2020 Sep 20]. Available from: http://www.redeblh.fiocruz.br/cgi/cgilua.exe/sys/start.htm?sid=352

17. who.int [Internet]. Eight Laureates for the Six Health Prizes Announced at WHA73 [cited 2021 Jan 10]. Available from: https://www.who.int/news-room/feature-stories/detail/eight-laureates-for-the-six-health-prizes-announced-at-wha73

18. Grovslihen AH, Gronn M. Donor milk banking and breastfeeding in Norway. J Hum Lac 2009;25(2):206-10.

19. Ramli N, Ibrahim NR. Human milk banks-the benefits and issues in an Islamic setting. EJM 2010;15(4):163.

20. Al- Quran, Surah al- Baqarah: $233,570 \mathrm{C}$

21. Kadıoğlu M, Şahin NH. Anne sütü bağışı: Türkiye'deki durum. Sağlık Bilimleri ve Meslekleri Dergisi 2014;1(2):102-14.

22. Czank $C$, et al. Retention of the immunological proteins of pasteurized human milk in relation to pasteurizer design and practice. Pediatr Res 2009;66(4):374-9.

23. Committee on Nutrition, Section on Breastfeeding, \& Committee on Fetus and Newborn. Donor human milk for the high-risk infant: preparation, safety, and usage options in the United States. Pediatrics 2017;139(1):e20163440.

24. Simmer K, Hartmann B. The knowns and unknowns of human milk banking. Early Hum Dev 2009;85(11):701-4.

25. Arnold LD. Global health policies that support the use of banked donor human milk: a human rights issue. Int Breastfeed J 2006;1(1):26.

26. Bharadva K, et al. Human milk banking guidelines. Indian Pediatr 2014;51(6):469-74.

27. efcni.org [Internet]. Recommendations for Promoting Human Milk Banks in Germany, Austria, and Switzerland [cited 2021 Jan 11]. Available from: https://www.efcni.org/wp-content/uploads/2018/05/2018_05_08_EFCNI_Positionpaper_web.pdf 
28. Altobelli $E$, et al. The impact of human milk on necrotizing enterocolitis: a systematic review and meta-analysis. Nutrients 2020;12(5):1322.

29. iums.ac.ir [Internet]. Breastfeeding A Guide for the Medical Profession [cited 2021 Jan 15]. Available from: https://iums.ac.ir/files/vch/files/laranc.pdf

30. unicef.org [Internet]. How A Human Milk Bank Works [cited 2021 Jan 12]. Available from: https://www.unicef.org/philippines/stories/how-human-milk-bank-works

31. Moro GE, Arslanoğlu S. Heat treatment of human milk. J Pediatr Gastroenterol Nutr 2012;54(2):165-6.

32. Kim JH, Unger S; Canadian Paediatric Society, \& Nutrition and Gastroenterology Committee. Human milk banking. Paed Child Healt 2010;15(9):595-8.

33. Picaud JC, Buffin R. Human milk-treatment and quality of banked human milk. Clin Perinatol 2017;44(1):95-119.

34. Gomes FP, et al. Effect of pasteurisation on the concentrations of vitamin D compounds in donor breastmilk. Int J Food Sci Nutr 2016;67(1):16-9.

35. Henderson TR, Fay TN, Hamosh M. Effect of pasteurization on long chain polyunsaturated fatty acid levels and enzyme activities of human milk. J Pediatr 1998;132(5):876-8.

36. Silvestre $D$, et al. Available lysine content in human milk: stability during manipulation prior to ingestion. Biofactors 2006;26(1):71-9.

37. Mehta R, Petrova A. Is variation in total antioxidant capacity of human milk associated with levels of bio-active proteins?. Am J Perinatol 2014;34(3): 220-2.

38. Hosein IK, et al. Summertime Bacillus cereus colonization of hospital newborns traced to contaminated, laundered linen. J Hosp Infect 2013;85(2):149-54.

39. Kaletunç G. Gıda endüstrisinde alışılmamış yöntemler. Bilim ve Teknik 2009;502(42):60-3.

40. Keskindemirci G. Anne Sütü Bankacılığı. Osmangazi Journal of Medicine 2020;Özel sayı:30-4.

41. Arslanoğlu S. Türkiye'de Anne Sütü Bankasının kuruluşu inanç ve değerlere uygun yeni bir model: Anne Sütü Merkezi. In: Kılıç i, Uçar A, editors. Süt akrabalı̆̆ı ve süt bankası. İstanbul (TR): İsar Yayınları; 2016. p. 55-61.

42. Gürol A, Özkan H, Çelebioğlu A. Turkish women's knowledge and views regarding mother's milk banking. Collegian 2014;21(3):239-244.

43. Ekşioğlu A, Yeşil Y, Turfan EÇ. Annelerin süt bankası hakkındaki görüşleri: İzmir örneği. Türk Pediatri Arşivi 2015;50(2):83-9. 